\title{
Response of Growth, Yield and Oil of Rapeseed to Sowing Method and Seeding Rate
}

\author{
Nazy Awishalem Sarkees \\ Field Crops Dept., College of Agriculture/ University of Salahaddin, Erbil/Iraq
}

\begin{abstract}
An experiment was conducted at Karda-Rasha /College of Agriculture-Erbil to evaluate the effect of different seeding rates using drill-row and broadcasting sowing methods on growth, seed and oil yields of rapeseed (Brassica napus L.) cv. Pactol. The results showed that drill-row sowing method produced seed and oil yields more than broadcasting method, particularly, at low seeding rates i.e. $4 \mathrm{~kg} \mathrm{ha}^{-1}$ seeding rate. Seeds grown by drill-row produced the highest number of plants $\mathrm{m}^{-2}$, the highest plants height and took the longest period for their flowering and seed formation; and produced a greater number of siliques plant ${ }^{-1}$ and greater weight of seed and then, higher seeds and oil yields. Seeds grown at higher seeding rates gave the higher number of plants $m^{-2}$ and higher silique surface area, with longest period for seed formation, the highest plants height bearing higher number of primary branches, higher harvest index and high oil percentage. However, seeds grown at low seeding rates, the period from sowing to flowering and flowering period were the longest. At $4 \mathrm{~kg} \mathrm{ha}^{-1}$ seeding rate produced higher number of siliques plant ${ }^{-1}$, greater weight of seed and higher seeds and oil yields. In this study, there was significant and positive correlation between number of siliques plant ${ }^{-1}$ and seed weight with total Yield. While there was a significant and negative correlation between harvest index and total yield. Also, positive and highly significant correlation between oil yield and total yield.
\end{abstract}

Keywords: Oil percentage, rapeseed, seeding rate, seed yield, sowing method

\section{Introduction}

Rapeseed (Brassica napus L.) is the important oilseed crops throughout the world which ranks third among the oilseed crops after soybean and oil palm in production of vegetable oils. (kauser et al., 2006). Canola oil is considered healthy for human nutrition due to its lowest content of saturated fatty acids among vegetable oils (Starner et al., 1999). Seed yield per hectare is of major importance to the production of any seed crop. The seed yield is a function of interaction between genetic and environmental factors including sowing method and seeding rate. The determination of a suitable sowing method and seeding rate for good agronomic performance is important. An understanding of the effects of the major agricultural practices which limits seed and oil yields of rapeseed is needed to develop improved technology relevant to Kurdistan conditions/Iraq. Seeding rate is considered an important factor to optimize plant production. The establishment of an adequate and uniform rapeseed stand is critical to achieve high grain yield. Seed yield of rapeseed is a function of population density, number of pods per plant, number of seeds per pod and seed weight. However, yield structure is very plastic and adjustable across a wide range of population (Diepenbrock, 2000). Some studied report that sowing method did influence of rapeseed, Nigussie et al., (1996) denoted response of Tower Set-3 and S-67 varieties to method of sowing were not consistent, in 1986 it was possible to increase yields by 4\% (S-67) and 30\% for Tower-Sel-3 for row-sowing, while in 1990 broadcasting turned out to be more advantageous. Drill-seeded material yielded more than broadcast material seeded at the same rate especially at the lower seeding rate (Clarke et al., 1978). Khan et al., (2000) illustrated that rapeseed yield and yield components was greatly increased when seeds were grown with ridge sowing, grain yield was higher by 45,31 and $28 \%$ than broadcast, drill and furrow sowing method respectively. In study by Shah and Rahman (2009) comprised six seeding rates from 2 to $12 \mathrm{~kg} \mathrm{ha}^{-1}$, they reported that the yield tended to increase with an increase in seed rate up to $10 \mathrm{~kg} \mathrm{ha}^{-1}$. Hanson et al., (2008) referred that seed yield increased with increasing at four seeding rates $(54,108,162$ and 216) pure live seed $\mathrm{m}^{-2}$. Angadi et al., (2003) noted that population reduced from 80 to 40 plants $\mathrm{m}^{-2}$ produced similar seed yield. Chen et al., (2005) found a seeding rate of 32 to 65 seeds $\mathrm{m}^{-2}$ was sufficient to produce optimum canola yield. Shahin and Valiollah (2009) found that an increase in seeding rate from 4 to $6 \mathrm{~kg} \mathrm{ha}^{-1}$ resulted in a decrease in number of pods plant ${ }^{-1}$, the highest number of pods plant ${ }^{-1}$ was obtained by applying $4 \mathrm{~kg} \mathrm{ha}^{-1}$ seeding rate. It was also observed that increasing seeding rate caused significant decrease in oil percentage (Naseralla, 2000). In contrast, seeding rates had no effect on yield seed and oil (Taylor and smith, 1992). The study was conducted to quantify the effects of sowing method and seeding rate on growth, seed and oil yields of rapeseed grown in Kurdistan Region/Iraq. 


\section{Materials And Methods}

A field study was conducted at the experimental farm, Gardrush/ College of AgricultureErbil/Kurdistan Region during winter season of 2011-2012 to study the response of growth, yield and oil rapeseed to sowding method and seeding rate. Split-plot based on randomized complete block design, with three replications. Experiment factors included two seeding method of drill-row and broadcasting (covered by hand) ranking as the main plots, five seeding rates: 4, 6, 8, 10 and $12 \mathrm{~kg} \mathrm{ha}^{-1}$ (with difference two kg between were tried each) as subplots. The subplot size was $5.4 \mathrm{~m}^{2}(1.8 \mathrm{~m} \mathrm{x} 3 \mathrm{~m})$ containing five rows, three $\mathrm{m}$ long and $30 \mathrm{~cm}$ apart, at a depth of 2-3 cm was used. The Brassica napus cv. Pactol was sown on 25, October 2011. Plots were watered for minimum of three hours and excess of water was allowed to drain from the surface. Weeds were removed by manual weeding during the growth stages. Nitrogen fertilizer was applied at the rate of $240 \mathrm{~kg} \mathrm{ha}^{-1}$ in the form of urea $(46 \% \mathrm{~N})$ at two intervals, the first at sowing date, and the second at flowering stage. Also $\mathrm{P}_{2} \mathrm{O}_{5}$ at rate of $90 \mathrm{~kg} \mathrm{ha}^{-1}$ was applied in the form of triple superphosphate $\left(46 \% \mathrm{P}_{2} \mathrm{O}_{5}\right)$ were drilled with seeds. Data was collected on some characteristics; the number of plants per $\mathrm{m}^{2}$ was taken at rosette growth stage (O.R.P.G., 2000) by randomly counting plants in one $30 \mathrm{~cm}$ row and $0.09 \mathrm{~m}^{2}$ of each plot for drill and broadcasting methods respectively, this way later converted into plants per $\mathrm{m}^{2}$. The number of days from sowing to the flowering was counted (flowering date was recorded as the day when $75 \%$ of the existing raceme were flowered. Daily observations were taken to obtain the number of days from sowing to the following growth stages to record both the period of flowering and seed formation.

1- First flower: It was recorded when $75 \%$ of the plants had at least three open flowers on the main raceme.

2- Last flower: It was recorded when $75 \%$ of the plants terminated flowering on the main raceme

3- Flowering period: Number of days from the first flower to the last flower.

4- Seed formation period; Number of days from the first flower to maturity of first pod (the plants had all black seeds in the lowest pod of the main raceme).

In the last flower, the measurement was made on surface area of pods, using the formula $2 \pi r h(r=$ half of the width of the pod at its middle point and $\mathrm{h}=$ the distance between the base of the pod) (Tayo and Morgan, 1975). At the time of maturity of the first pod of main raceme per plant, plant height, number of primary branches and number of siliques plant ${ }^{-1}$ were counted after harvest three plants per plot and then divided by three. Number of seeds silique ${ }^{-1}$ was also determined from three plants sample, fifty pods from all three plants was taken, threshed and the number of seeds per silique were counted. The seed weight was recorded by counting 500 seeds from each silique sample, then seeds were dried at $30^{\circ} \mathrm{C}$ in a forced air dryer, weighed and then seed weight rate (mg) was counted. Actual harvest time was 2-4 days after maturity of first silique on the main raceme for each plot. Total yield was obtained by cutting the plants sample from the center row $(30 \mathrm{~cm} \mathrm{x}$ $300 \mathrm{~cm})=0.9 \mathrm{~m}^{2}$ for drill-row and centered $2 \mathrm{~m}^{2}$ for broadcasting seeding to count seed yield and then converted into yield per hectare. To record harvest index, harvested crop which included seeds + stems + leaves were weighed after drying by exposing it to sunlight to record biological yield in kilograms per hectare and the seed yield divided biological yield to recorded harvest index multiple 100. Oil content of the seed was determined by the Soxhlet and oil yield was recorded by percentage oil multiply by seed yield. The obtained data was subjected to variance analysis as a split-plot design using the statistical analysis system (SAS Institute, 2005). Least significant difference was the statistical method used to determine differences among means.

\section{1- Effect of sowing methods on some characteristics of rapeseed \\ III. Results And Discussion}

There were no significant differences among sowing methods for number of days from sowing to flowering, surface area of siliques, number of primary branches of plant, number of seeds of silique and harvest index, while sowing methods showed significant effect on rest traits of rapeseed (Table 1 and 2). Analysis of variance regarding number of plants $\mathrm{m}^{-2}$ indicated significant effect of sowing methods, highest counts for number of plants $\mathrm{m}^{-2}$ of rapeseed noted with drill-row sowing, while the lowest counts were recorded with broadcasting sowing (Table 1). This result is in agreement with the work of Khan et al., (2000) and not in agreement with Khan and Muendel (2002) which they pointed out that the number of plant stand did not significantly differ with various sowing methods. The drill-row method had a significantly longer flowering and seed formation periods than broadcasting at four and eight days respectively. The tallest plants were produced in the drill-row sown plots. $(129.5 \mathrm{~cm})$, while the shortest plants were produced with broadcasting sowing $(115.2$ $\mathrm{cm})$ (Table 1), this result is in agreement with Khan et al., (2000) that the plants of broadcasting sowing are shorter $(109.7 \mathrm{~cm})$ than plants of drill sowing method $(118.0 \mathrm{~cm})$. Individual plants of drill-row sowing produced a higher number of siliques than those of broadcasting sowing (130.0) and (107.1) siliques 9plant ${ }^{-1}$ respectively (Table 2), this result is not in agreement with results of Nigussie et al., (1996) which illustrated that broadcasting significantly favored the pod-bearing capacity comparable with row sowing (301 and 233 pod plant $^{-1}$ ) respectively. Similar to number of pod plant ${ }^{-1}$, weight of seed play a major role in yield. Crop grown with drill-row sowing method showed significantly highest seed weight as compared to broadcasting which 
produced lowest seed weight (Table 2), this result is in agreement with the work of Khan et al., (2000). Similarly, maximum total yield of $1091.9 \mathrm{~kg} \mathrm{ha}^{-1}$ was obtained when crop was grown by drill-row sowing, which was significantly higher than broadcasting of $140.9 \%$, similar results were reported by Khan et al., (2000). Oil percentage was not significantly affected by sowing method, but oil yields were significantly affected, it increased by $148.9 \%$ for drill-row, the decline in the total yields of broadcasting was due to its lower oil yields (Table 2), similar result was reported by Nigussie et al., (1996).

\section{2- Effect of seeding rates on some characteristics of rapeseed}

Although the number of plants $\mathrm{m}^{-2}$ was increased by the seeding rate treatments (Table 3), the number of plants $\mathrm{m}^{-2}$ was mainly greater in the high seeding rates plots, for example, 244.45 and 268.52 plants $\mathrm{m}^{-2}$ were recorded for treatments 10 and $12 \mathrm{~kg} \mathrm{ha}^{-1}$ respectively as compared with the rest of seeding rates, this result is in agreement with the results of Scarisbrick et al., (1982), Taylor and Smith (1992) and Hanson et al., (2008). At $12 \mathrm{~kg} \mathrm{ha}^{-1}$ seeding rate resulted in the fewest days to first flower (149 days) as comparable of the rest of seeding rates (Table 3). The number of days from seeding to flowering (first flower) seems to be good indication of maturity of first silique. Seeds sown by highest seeding rates, led to shortening and prolonged flowering and seed formation periods, respectively, for example, the $12 \mathrm{~kg} \mathrm{ha}^{-1}$ seeding rate shortened to 34.2 and prolonged to 49.2 days respectively comparing with the lowest seeding rates $\left(4\right.$ and $\left.6 \mathrm{~kg} \mathrm{ha}^{-1}\right)$. Increased seeding rates resulted in a reduction of days to growth stages subsequent to first flower and duration of flowering and increased seed formation periods (Degenhardt and Kondra, 1981b). On all traits, surface area of siliques, plant height and number of primary branches of plant differed over seeding rates, at $10 \mathrm{~kg} \mathrm{ha}^{-1}$ seeding rate, surface area of silique, plant height and the number of primary branches of plants increased $\left(928.33 \mathrm{~mm}^{2}, 141.0 \mathrm{~cm}\right.$ and 5.5 branch plant $^{-1}$ ) respectively compared with the total seeding rates (Table 3). The result of plant height is not in agreement with results of Hanson et al., (2008); Shah and Rahman (2009) and Shahin and Valiollah (2009) which showed that seeding rates did not significantly affected plant height. The obtained results indicated that number of siliques plant ${ }^{-1}$ was influenced by different seeding rates (Table 4), the number of siliques plant ${ }^{-1}$ decreased $47.1 \%$ as the seeding rate increased from 4 to $12 \mathrm{~kg} \mathrm{ha}^{-1}$, the number of siliques plant ${ }^{-1}$ is the most responsive of all the yield components in rapeseed, this result agrees with those of Scarisbrick et al., (1982); Leach et al., (1999) and Shahin and Vaiolah (2009). It is noted from (Table 4) that there is no differences between the seeding rates 4, 6, 8 and $10 \mathrm{~kg} \mathrm{ha}^{-1}$ among them in seeds/silique trait, however the four previous seeding rates were different from $12 \mathrm{~kg} \mathrm{ha}^{-1}$ seeding rate which the number of seeds/silique decreased to 19.13 seed/silique. For the same table, it is noted that there is no differences among the seeding rates 6, 8, 10 and 12 $\mathrm{kg} \mathrm{ha}^{-1}$ in seed weight, however the seed weight at $4 \mathrm{~kg} \mathrm{ha}^{-1}$ seeding rate has increased $18 \%$ compared to the higher four seeding rates, that is due to the increase of the number of plants $\mathrm{m}^{2}$, plant height, number of primary branches plant $^{-1}$ (Table 3), which led to increase of competition between plants over growth factors, consequently led to decrease of number of siliques plant ${ }^{-1}$ and seed weight. Rate of seeding showed significant effect on total yield (table 4). The low seeding rate $\left(4 \mathrm{~kg} \mathrm{ha}^{-1}\right)$ resulted in the highest average yield $(1037.3 \mathrm{~kg}$ $\mathrm{ha}^{-1}$ ), which is not in agreement with the previous work of Taylor and Smith (1992), Jambor (2007), Shahin and Valiolah (2009) who concluded that seeding rates were not influenced on seed yield and not agrees with Hanson et al., (2008) and Shah and Rahman (2009) who illustrated that seed yield increased with increasing seeding rates. There was a significant decrease and increase in harvest index at the 4 and $12 \mathrm{~kg} \mathrm{ha}^{-1}$ seeding rate respectively, due to the possible advantage of reduced and raised branching or number of primary branches of plant for these treatment ( 4 and $12 \mathrm{~kg} \mathrm{ha}^{-1}$ ) respectively (Table3). Oil percentage tended to decrease from $36.17 \%$ to $27.50 \%$ when seeding rate decreased from 12 to $8 \mathrm{~kg} \mathrm{ha}^{-1}$, while oil yield tended to decrease $22 \mathrm{t} \mathrm{ha}^{-1}$ when seeding rate was increased from 4 to $12 \mathrm{~kg} \mathrm{ha}^{-1}$, this result was not in agreement with Chen et al., (2005) which had reported that oil content tended to decrease from 20 to $10 \mathrm{~g} \mathrm{~kg}^{-1}$ when seeding rate was increased from 11 to 97 seed $\mathrm{m}^{-2}$

\section{3- Effect of interaction between sowing methods and seeding rates on some characteristics of rapeseed}

The interaction effect of sowing methods with seeding rates on all characteristics studied was also significant. The highest value of total yield was $\left(1344 \mathrm{~kg} \mathrm{ha}^{-1}\right)$ for rapeseed sown at drill-row with the low seeding rate $\left(4 \mathrm{~kg} \mathrm{ha}^{-1}\right)$ because of number of siliques plant ${ }^{-1}$ increase (152.67 silique) or increasing of seed weight $(0.21 \mathrm{mg}$ ) (Table 6). This result is in accord with Clarke et al., (1978) who indicated that drill seeded material yielded more than broadcast material seeded at the same rate, especially at low seeding rates. In both sowing methods, each increase in seeding rate resulted in a significant decrease in yield, and this result was in accord with Khan and Muendel (2002) who concluded that seed yield was the highest at the seeding rate $4 \mathrm{~kg}$ $\mathrm{ha}^{-1}$ with straight line seeding. It is obvious that the interaction effect of sowing methods with seeding rates on oil percentage and oil yields were also significant, the highest value of them were $\left(38.33 \%\right.$ and $\left.39834 \mathrm{~kg} \mathrm{ha}^{-1}\right)$ for seeds sown by drill-row with 12 and $4 \mathrm{~kg} \mathrm{ha}^{-1}$ respectively (Table 6), due to increase of total yield which in turn led to increase of oil yield. 
Referring to table (7), the flowering period had a positive correlation with total yield, and with seed formation period at $(0.669$ and 0.719$)$ respectively. In this study, number of siliques plant ${ }^{-1}$ and seed weight had significant and positive correlation with total yield. Therefore, any agronomical performance with the aim of increasing of number of siliques plant ${ }^{-1}$ and seed weight would result in increase in seed yield. The harvest index was negatively correlated with total yield. It is clear from the relationship study (Table 7) that oil yields were positively and highly significant correlated with the total yield (0.966).

Based on results of this study. It could be concluded that sowing methods and sowing rates had significant influence on growth, yield and its components of rapeseed. A drill-row seeding method and $4 \mathrm{~kg} \mathrm{ha}^{-1}$ seeding rate produced higher seed and oil yields of rapeseed cv. Pactol in Erbil/Kurdistan Region.

Table 1. Effect of sowing methods on some characteristics of rapeseed

\begin{tabular}{|c|c|c|c|c|c|c|c|}
\hline $\begin{array}{c}\text { Sowing } \\
\text { method }\end{array}$ & $\begin{array}{c}\text { No. of } \\
\text { plants } \\
\mathrm{m}^{-2}\end{array}$ & $\begin{array}{c}\text { No. of days } \\
\text { from sowing } \\
\text { to flowering } \\
\text { (day) }\end{array}$ & $\begin{array}{c}\text { Flowering } \\
\text { period } \\
\text { (day) }\end{array}$ & $\begin{array}{c}\text { Seed } \\
\text { formation } \\
\text { period } \\
\text { (day) }\end{array}$ & $\begin{array}{c}\text { Surface } \\
\text { area } \\
\text { of siliques } \\
\left(\mathrm{mm}^{2}\right)\end{array}$ & $\begin{array}{c}\text { Plant } \\
\text { height } \\
(\mathrm{cm})\end{array}$ & $\begin{array}{c}\text { No. of } \\
\text { primary } \\
\text { branches of } \\
\text { plant }\end{array}$ \\
\hline Drill-Row & 211.77 & 151.87 & 37 & 49.5 & 779.19 & 129.5 & 4.8 \\
\hline Broadcasting & 107.41 & 154.27 & 33 & 41.3 & 829.52 & 115.2 & 3.6 \\
\hline LSD $_{0.05}$ & 62.13 & NS & 2.8 & 5.6 & NS & 12.2 & NS \\
\hline
\end{tabular}

Table 2. Effect of sowing methods on yield, yield components and oil of rapeseed

\begin{tabular}{|c|c|c|c|c|c|c|c|}
\hline $\begin{array}{c}\text { Sowing } \\
\text { method }\end{array}$ & $\begin{array}{c}\text { No. of } \\
\text { siliques of } \\
\text { plant }\end{array}$ & $\begin{array}{c}\text { No. of seeds } \\
\text { of silique }\end{array}$ & $\begin{array}{c}\text { Weight of } \\
\text { seed } \\
(\mathrm{mg})\end{array}$ & $\begin{array}{c}\text { Total } \\
\text { yield } \\
\left(\mathrm{kg} \mathrm{ha}^{-1}\right)\end{array}$ & $\begin{array}{c}\text { Harvest } \\
\text { Index } \\
(\%)\end{array}$ & $\begin{array}{c}\text { Oil } \\
\text { percentage } \\
(\%)\end{array}$ & $\begin{array}{c}\text { Oil } \\
\text { yield } \\
\left(\mathrm{kg} \mathrm{ha}^{-1}\right)\end{array}$ \\
\hline Drill-Row & 130.0 & 21.09 & 0.17 & 1091.9 & 32.1 & 31.47 & 34146 \\
\hline Broadcasting & 107.1 & 23.16 & 0.15 & 453.3 & 37.8 & 30.67 & 13719 \\
\hline LSD $_{0.05}$ & 21.3 & NS & 0.01 & 216.9 & NS & NS & 6586.1 \\
\hline
\end{tabular}

Table 3. Effect of seeding rates on some characteristics of rapeseed

\begin{tabular}{|c|c|c|c|c|c|c|c|}
\hline $\begin{array}{c}\text { Seeding } \\
\text { rates } \\
\left(\mathrm{kg} \mathrm{ha}^{-1}\right)\end{array}$ & $\begin{array}{c}\text { No of plants } \\
\mathrm{m}^{-2}\end{array}$ & $\begin{array}{c}\text { No. of days } \\
\text { from sowing } \\
\text { to flowering } \\
(\text { day) }\end{array}$ & $\begin{array}{c}\text { Flowering } \\
\text { period } \\
(\text { day) }\end{array}$ & $\begin{array}{c}\text { Feed } \\
\text { Formation } \\
\text { period } \\
(\text { day })\end{array}$ & $\begin{array}{c}\text { Surface area } \\
\text { of siliques } \\
\left(\mathrm{mm}^{2}\right)\end{array}$ & $\begin{array}{c}\text { Plant } \\
\text { height } \\
(\mathrm{cm})\end{array}$ & $\begin{array}{c}\text { No. of } \\
\text { primary } \\
\text { branches of } \\
\text { plant }\end{array}$ \\
\hline 4 & 55.33 & 153.83 & 37.3 & 42.7 & 816.60 & 123.2 & 3.7 \\
\hline 6 & 90.75 & 155.33 & 37.3 & 43.2 & 742.05 & 100.0 & 3.8 \\
\hline 8 & 138.90 & 152.83 & 34.7 & 43.3 & 791.00 & 119.3 & 3.8 \\
\hline 10 & 244.45 & 154.33 & 35.3 & 44.5 & 928.33 & 141.0 & 5.5 \\
\hline 12 & 268.52 & 149.00 & 34.2 & 49.2 & 743.78 & 138.2 & 5.2 \\
\hline $\mathrm{LSD}_{0.05}$ & 30.96 & 2.70 & 2.1 & 3.2 & 62.47 & 8.5 & 1.3 \\
\hline
\end{tabular}

Table 4. Effect of seeding rates on yield, yield components and oil of rapeseed

\begin{tabular}{|c|c|c|c|c|c|c|c|}
\hline $\begin{array}{c}\text { Seeding } \\
\text { rates } \\
\left(\mathrm{Kg} \mathrm{ha}^{-1}\right)\end{array}$ & $\begin{array}{c}\text { No. of } \\
\text { siliques of } \\
\text { plant }\end{array}$ & $\begin{array}{c}\text { No. of } \\
\text { seeds of } \\
\text { silique }\end{array}$ & $\begin{array}{c}\text { Weight } \\
\text { of seed } \\
(\mathrm{mg})\end{array}$ & $\begin{array}{c}\text { Total } \\
\text { yield } \\
\left(\mathrm{kg} \mathrm{ha}^{-1}\right)\end{array}$ & $\begin{array}{c}\text { Harvest } \\
\text { Index } \\
(\%)\end{array}$ & $\begin{array}{c}\text { Oil } \\
\text { percentage } \\
(\%)\end{array}$ & $\begin{array}{c}\text { Oil } \\
\text { yield } \\
\left(\mathrm{kg} \mathrm{ha}^{-1}\right)\end{array}$ \\
\hline 4 & 140.0 & 21.37 & 0.18 & 1037.3 & 31.4 & 30.17 & 31109 \\
\hline 6 & 129.7 & 22.87 & 0.16 & 797.4 & 36.1 & 29.67 & 23852 \\
\hline 8 & 115.5 & 22.87 & 0.16 & 741.1 & 34.9 & 27.50 & 20268 \\
\hline 10 & 112.3 & 24.40 & 0.15 & 698.5 & 33.3 & 31.83 & 22307 \\
\hline 12 & 95.2 & 19.13 & 0.15 & 588.7 & 39.1 & 36.17 & 22126 \\
\hline $\mathrm{LSD}_{0.05}$ & 42.2 & 3.91 & 0.02 & 109.8 & 5.9 & 1.54 & 3146.2 \\
\hline
\end{tabular}

Table 5. Effect of sowing methods and seeding rates interaction on some characteristics

\begin{tabular}{|c|c|c|c|c|c|c|c|c|}
\hline $\begin{array}{c}\text { Sowing } \\
\text { method }\end{array}$ & $\begin{array}{c}\text { Seeding } \\
\text { rates } \\
\left(\mathrm{kg} \mathrm{ha}^{-1}\right)\end{array}$ & $\begin{array}{c}\text { No. of } \\
\text { plants } \\
\mathrm{m}^{-2}\end{array}$ & $\begin{array}{c}\text { Noys from } \\
\text { sowing } \\
\text { to } \\
\text { flowering } \\
\text { (day) }\end{array}$ & $\begin{array}{c}\text { Flowering } \\
\text { period } \\
\text { (day) }\end{array}$ & $\begin{array}{c}\text { Seed } \\
\text { formation } \\
\text { period } \\
\text { (day) }\end{array}$ & $\begin{array}{c}\text { Surface } \\
\text { area } \\
\text { of } \\
\text { siliques } \\
\left(\mathrm{mm}^{2}\right)\end{array}$ & $\begin{array}{c}\text { Plant } \\
\text { height } \\
(\mathrm{cm})\end{array}$ & $\begin{array}{c}\text { No. of } \\
\text { primary } \\
\text { branches } \\
\text { of } \\
\text { plant }\end{array}$ \\
\hline \multirow{4}{*}{ Drill-Row } & 4 & 69.9 & 150.7 & 39.67 & 48.00 & 720 & 148.3 & 4.0 \\
\cline { 2 - 9 } & 6 & 107.4 & 155.0 & 40.67 & 52.67 & 851 & 104.0 & 4.3 \\
\cline { 2 - 9 } & 10 & 181.5 & 151.3 & 38.00 & 49.33 & 771 & 122.0 & 4.3 \\
\hline
\end{tabular}


Response of Growth, Yield and Oil of Rapeseed to Sowing Method and Seeding Rate

\begin{tabular}{|c|c|c|c|c|c|c|c|c|}
\hline & 12 & 363.0 & 145.7 & 36.67 & 52.67 & 731 & 119.0 & 6.3 \\
\hline \multirow{4}{*}{ Broadcasting } & 4 & 40.7 & 157.0 & 34.33 & 37.33 & 913 & 98.0 & 3.3 \\
\cline { 2 - 9 } & 6 & 74.1 & 155.7 & 34.00 & 41.67 & 633 & 96.0 & 3.3 \\
\cline { 2 - 9 } & 8 & 96.3 & 154.3 & 31.33 & 37.33 & 811 & 116.7 & 3.3 \\
\cline { 2 - 9 } & 10 & 151.9 & 152.0 & 34.67 & 44.33 & 1035 & 128.0 & 4.0 \\
\cline { 2 - 9 } & 12 & 174.1 & 152.3 & 33.67 & 45.67 & 756 & 137.3 & 4.0 \\
\hline \multicolumn{2}{|c|}{ LSD $_{0.05}$} & 27.3 & 2.1 & 1.69 & 2.40 & 50.2 & 15.8 & 2.4 \\
\hline
\end{tabular}

Table 6. Effect of sowing methods and seeding rates interaction on yield, yield components and oil of rapeseed

\begin{tabular}{|c|c|c|c|c|c|c|c|c|}
\hline $\begin{array}{c}\text { Sowing } \\
\text { method }\end{array}$ & $\begin{array}{c}\text { Seeding } \\
\text { rates } \\
\left(\mathrm{kg} \mathrm{h}^{-1}\right)\end{array}$ & $\begin{array}{c}\text { No. of } \\
\text { siliques } \\
\text { plant })\end{array}$ & $\begin{array}{c}\text { No of } \\
\text { seeds/ } \\
\text { silique }\end{array}$ & $\begin{array}{c}\text { Seed } \\
\text { weight } \\
(\mathrm{mg})\end{array}$ & $\begin{array}{c}\text { Total } \\
\text { yield } \\
\left(\mathrm{kg} \mathrm{ha}^{-1}\right)\end{array}$ & $\begin{array}{c}\text { Harvest } \\
\text { Index } \\
(\%)\end{array}$ & $\begin{array}{c}\text { Oil } \\
\text { percentage }\end{array}$ & $\begin{array}{c}\text { Oil } \\
\text { yield } \\
\left(\mathrm{kg} \mathrm{h}^{-1}\right)\end{array}$ \\
\hline \multirow{5}{*}{ Drill-Row } & 4 & 152.67 & 18.47 & 0.21 & 1344 & 35.63 & 29.67 & 39834 \\
\cline { 2 - 9 } & 6 & 138.00 & 24.00 & 0.16 & 1102 & 33.23 & 30.33 & 33441 \\
\cline { 2 - 9 } & 8 & 131.00 & 20.73 & 0.17 & 1047 & 30.77 & 27.00 & 28272 \\
\cline { 2 - 9 } & 10 & 120.67 & 26.33 & 0.15 & 991 & 31.07 & 32.00 & 31769 \\
\hline \multirow{5}{*}{ Broadcasting } & 12 & 107.67 & 15.93 & 0.14 & 975 & 29.67 & 38.33 & 37411 \\
\cline { 2 - 9 } & 4 & 127.33 & 24.27 & 0.15 & 731 & 27.23 & 30.67 & 22383 \\
\cline { 2 - 9 } & 6 & 121.33 & 21.73 & 0.16 & 493 & 38.93 & 29.00 & 14264 \\
\cline { 2 - 9 } & 100.00 & 25.00 & 0.15 & 435 & 39.07 & 28.00 & 12265 \\
\cline { 2 - 9 } & 10 & 104.00 & 22.47 & 0.15 & 406 & 35.50 & 31.67 & 12844 \\
\hline \multicolumn{2}{|c|}{ LSD $_{0.05}$} & 82.67 & 22.33 & 0.15 & 202 & 48.43 & 34.00 & 6841 \\
\hline
\end{tabular}

Table 7. Correlation coefficient analysis among the traits of rapeseed

\begin{tabular}{|c|c|c|c|c|c|c|c|c|c|c|c|c|c|c|}
\hline & $\begin{array}{c}\text { Total } \\
\text { yield } \\
\left(\mathrm{kg} \mathrm{ha}^{-1}\right)\end{array}$ & $\begin{array}{l}\text { No. of } \\
\text { plants } \\
\mathrm{m}^{-2}\end{array}$ & $\begin{array}{c}\text { No of } \\
\text { days from } \\
\text { seeding } \\
\text { to flowering } \\
\text { (day) }\end{array}$ & $\begin{array}{l}\text { Floweri } \\
\text { ng } \\
\text { period } \\
\text { (day) }\end{array}$ & $\begin{array}{c}\text { Seed } \\
\text { formati } \\
\text { on } \\
\text { period } \\
\text { (day) } \\
\end{array}$ & $\begin{array}{c}\text { Surface } \\
\text { area } \\
\text { of } \\
\text { siliques } \\
\left(\mathrm{mm}^{2}\right) \\
\end{array}$ & $\begin{array}{l}\text { Plant } \\
\text { height } \\
(\mathrm{cm})\end{array}$ & $\begin{array}{c}\text { No. of } \\
\text { primary } \\
\text { branches } \\
\text { of } \\
\text { plant }\end{array}$ & $\begin{array}{c}\text { No. of } \\
\text { silique } \\
s \\
\text { plant }\end{array}$ & $\begin{array}{l}\text { No of } \\
\text { seeds/ } \\
\text { silique }\end{array}$ & $\begin{array}{c}\text { Seed } \\
\text { weight } \\
\text { (mg) }\end{array}$ & $\begin{array}{l}\text { Harve } \\
\text { st } \\
\text { Index } \\
(\%)\end{array}$ & $\begin{array}{l}\text { Oil } \\
\text { percenta } \\
\text { ge } \\
(\%)\end{array}$ & $\begin{array}{c}\text { Oit } \\
\text { yield } \\
\left(\mathrm{kg} \mathrm{ha}^{-1}\right)\end{array}$ \\
\hline $\begin{array}{l}\text { No. of } \\
\text { plants } \mathrm{m}^{-2}\end{array}$ & $0.163^{*}$ & 1.00 & & & & & & & & & & & & \\
\hline $\begin{array}{l}\text { No of } \\
\text { Days from } \\
\text { Seeding } \\
\text { To } \\
\text { flowering }\end{array}$ & $-0.165^{*}$ & $-0.339 *$ & 1.00 & & & & & & & & & & & \\
\hline $\begin{array}{c}\text { Flowering } \\
\text { period }\end{array}$ & $0.669^{* *}$ & -0.023 & $0.271^{*}$ & 1.00 & & & & & & & & & & \\
\hline $\begin{array}{l}\text { Seed } \\
\text { Formation } \\
\text { period }\end{array}$ & $0.445^{* *}$ & $0.337^{* *}$ & $-0.495^{* *}$ & $0.719^{* *}$ & 1.00 & & & & & & & & & \\
\hline $\begin{array}{c}\text { Surface } \\
\text { Area } \\
\text { of siliques }\end{array}$ & $-0.146^{*}$ & -0.080 & $0.240^{*}$ & -0.124 & $-0.199 *$ & 1.00 & & & & & & & & \\
\hline $\begin{array}{r}\text { Plant } \\
\text { height }\end{array}$ & $0.203^{*}$ & $0.438^{* *}$ & $-0.252^{*}$ & 0.057 & $0.215^{*}$ & -0.051 & 1.00 & & & & & & & \\
\hline $\begin{array}{c}\text { No. of } \\
\text { Primary } \\
\text { Branches } \\
\text { of } \\
\text { plant }\end{array}$ & $0.265^{*}$ & $0.475^{* *}$ & $-0.409^{* *}$ & $0.241^{*}$ & $0.514^{* *}$ & -0.009 & $0.223^{*}$ & 1.00 & & & & & & \\
\hline $\begin{array}{l}\text { No. of } \\
\text { Siliques/ } \\
\text { plant }\end{array}$ & $0.528^{* *}$ & $-0.203^{*}$ & $0.018^{*}$ & $0.562^{* *}$ & $0.148^{*}$ & -0.049 & 0.029 & 0.036 & 1.00 & & & & & \\
\hline $\begin{array}{l}\text { No. of } \\
\text { Seeds/ } \\
\text { silique }\end{array}$ & $-0.181^{*}$ & $-0.170^{*}$ & $0.639^{* *}$ & $0.341^{* *}$ & $0.473^{* *}$ & $0.339^{* *}$ & -0.099 & $-0.324^{*}$ & -0.064 & 1.00 & & & & \\
\hline $\begin{array}{c}\text { Seed } \\
\text { weight }\end{array}$ & $0.476^{* *}$ & $-0.293^{*}$ & -0.039 & $0.436^{* *}$ & $0.130^{*}$ & $-0.209^{*}$ & $0.292^{*}$ & -0.044 & $0.149^{*}$ & $-0.282^{*}$ & 1.00 & & & \\
\hline $\begin{array}{l}\text { Harvest } \\
\text { Index }\end{array}$ & $-0.572^{* *}$ & $-0.227^{*}$ & -0.077 & $-0.232^{*}$ & 0.001 & $-0.236^{*}$ & 0.122 & $-0.207^{*}$ & $0.205^{*}$ & 0.057 & -0.048 & 1.00 & & \\
\hline $\begin{array}{c}\text { Oil } \\
\text { percentage }\end{array}$ & -0.058 & $0.641^{* *}$ & $-0.391^{*}$ & -0.072 & 0.251 & 0.027 & 0.156 & $0.319^{*}$ & -0.299 & -0.299 & -0.274 & -0.096 & 1.00 & \\
\hline $\begin{array}{c}\text { Oil } \\
\text { yield }\end{array}$ & $0.966^{* *}$ & $0.327^{*}$ & -0.245 & $0.610^{* *}$ & $0.479^{*}$ & -0.141 & 0.205 & $0.341^{*}$ & $0.326^{*}$ & -0.246 & $-0.376^{*}$ & $\underset{*}{0.603^{*}}$ & 0.186 & 1.00 \\
\hline
\end{tabular}

*Significant at 0.05 level $\quad$ ** Significant at 0.01 level 


\section{References}

[1] Kauser, R. H. R. Athar and M. Ashraf. 2006. Chlorophyll fluorescence can be used as a potential indicator for rapid assessment of water stress tolerance in Canada (Brassica napus L.). Pak. J. Bot., 38(5): 1501-1510

[2] Starner, D. E. A. A. Hamama and L. Bhardwaj. 1999. Canola oil yield and quality as affected by production practices in Virginia. In Janick J., (ed.) Perspective on new crops and new uses, ASMS Press, Alexandria, VA. pp. 254-256

[3] Diepenbrock, W. 2000. Yield analysis of winter oilseed rape (Brassica napus L.): A review, Field crops Res. 67: 35-49

[4] Nigussie, A., T. Adefris and T. Zerihum. 1996. Effect of agronomic practices on seed and oil yields of Ethiopian mustard (Brasica carinata A. Braun) and rapeseed (Brassica napus L.) Trop. Agric. 73(2): 94-99

[5] Clarke, J. M., F. R. Clarke, and G. M. Simpson. 1978. Effects of method and rate of seeding on yield of Brassica napus. Can. J. Plant Sci. 58: 549-550

[6] Khan, M. J., R. A. Khattak and M. A. khan. 2000. Influence of sowing methods on the productivity of canola grown in saline field. Pak. J. Biological Sci. 3(4): 687-691

[7] Shah, A. S., and K. Rahman. 2009. Yield and growth response of rapeseed (Brassica napus L.) mutants to different seeding rates and sowing dates. Pak. J. Bot., 41(6): 2711-2716

[8] Hanson, B. K., B. L. Johnson, R. A. Henson, and N. R. Riveland. 2008. Seeding rate, seeding depth and cultivar influence on spring canola performance in the Northern Great Plains. Agron. J. 100(5): 1339-1346

[9] Angadi, S. V., H. W. Culforch, B. C. McConkey, and Y. Gan.2003. Yield adjustment by canola growth at different plant population under semi-arid conditions. Crop Sci. 43: 1358-1366

[10] Chen, C., G. Jackson, K. Heill, D. Wichman, G. Johnson, and D. Johnson. 2005. Determining the feasibility of early seeding canola in the Northern Great Plains. Agron. J. 97: 1252-1262

[11] Shahin, Y., and R. Valiollah. 2009. Effects of row spacing and seeding rates on some agronomical traits of spring canola (Brassica napus L.) cultivars. Central European of J. Agriculture. 10(1); 115-122.

[12] Naseralla, A. Y. 2000. Effect of seeding rate on growth and quality characteristics of two species of Brassica. The Iraqi Journal of Agricultural Science. 31(2): 273-282 (in Arabic)

[13] Taylor, A. J., and G. J. Smith. 1992. Effect of sowing date and seeding rate on yield and yield components of irrigated canola (Brassica napus L.) grown on a red-brown earth in South-Eastern Australia. Aust. J. Agric. Res. 43: 1629-1641

[14] Oilseed Rape, Pocket Guide (O. R. P. G), 2000 PEIG seeds, Monsanto, Trumpington. Cambridge

[15] Tayo, T. O., and D. G. Morgan, 1975. Quantitative analysis of the growth, development and distribution of flowers and pods in oilseed rape (Brassica napus L.). J. Agric. Sci., Camb. 85; 103-110

[16] SAS, 2005. Statistical analysis system. SAS Institute. Inc., Cary, NC, USA. Release 82

[17] Khan, R., and H. H. Muendel, 2002. Optimum seeding rates for rainfed and irrigated rapeseed and mustard production in Islamabad, Pakistan. J. Agric. Res. 17(1): 27-32

[18] Scasrisbrick, D. H., R. W. Daniel, and A. B. Noor Rawi, 1982. The effect of varying seed rate on the yield and yield components of oilseed rape (Brassica napus L.). J. Agric. Sci., Camb. 99: 561-568

[19] Degenhardt, D. F., and Z. P. Kondra. 1981(b). Influence of seeding date and seeding rate on seed yield and growth characteris tics five genotypes of Brassica napus. Can. J. Plant Sci. 61: 185-190

[20] Leach, J. E., M. J. Stevenson, A. J., Rainbow, and L. A., Mullen. 1999. Effects of plant population on the growth and yield of winter oilseed rape (Brassica napus L.). J. Agric. Sci., Cambridge. 132: 173-180

[21] Jambor, M., 2007. Effect of seeding rate and seeding date on creation of yield of selected winter oilseed rape varieties and hybrids. Journal for Agricultural Science. 53(1): 49-57 